\title{
Housing the Poor in West Africa : Public and Private Provision
}

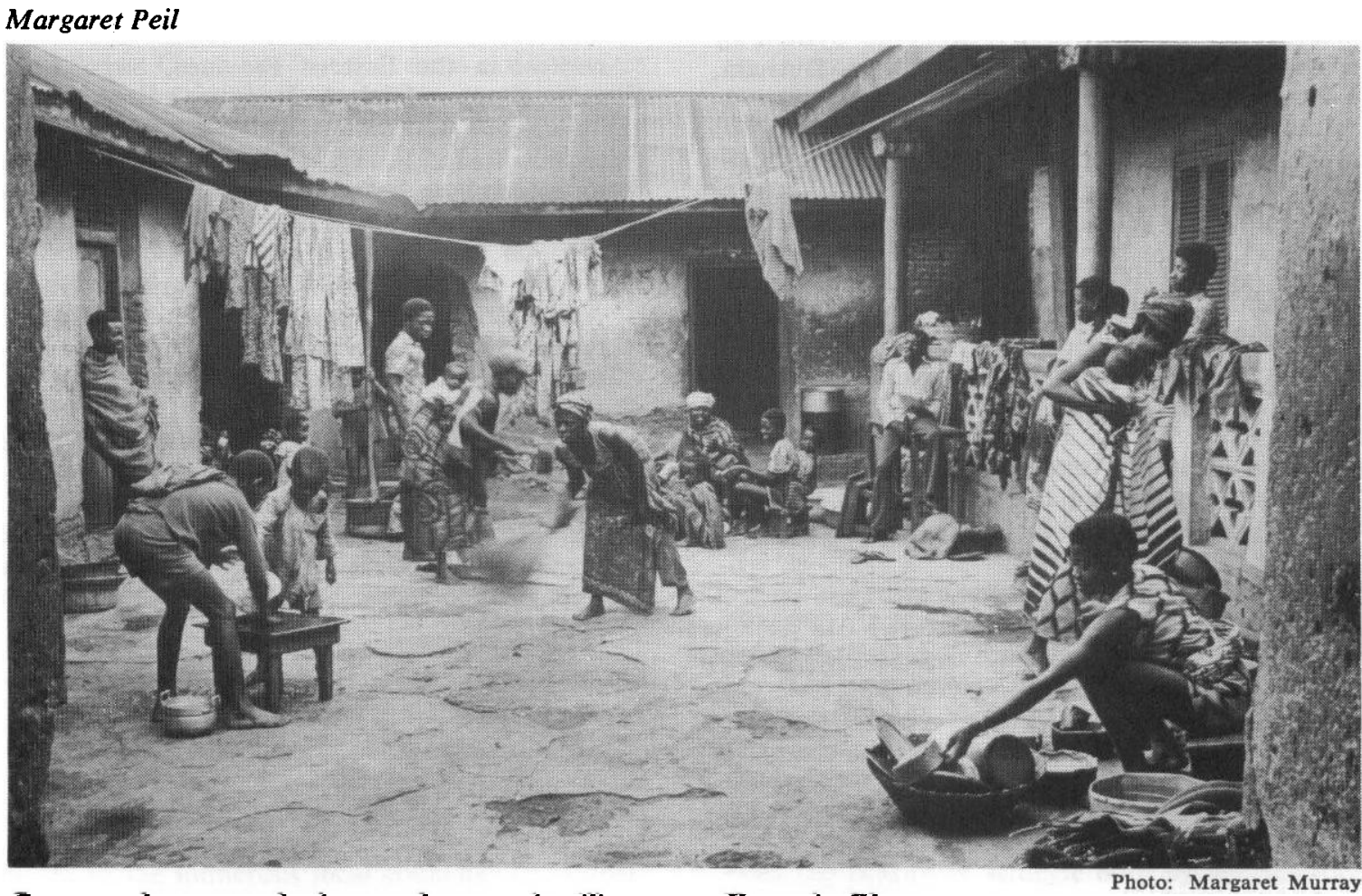

Communal courtyard of several cocoa families, near Kumasi, Ghana.

Photo: Margaret Murray

Planned urban housing has a long history in West Africa, though far more attention has been paid to the needs of the elites (and, more recently, middle income groups) than to the poor. Most public housing during the colonial period was built for Europeans. Certain groups of employees (miners, railway workers, police) were also catered for to some extent. Estates for the general public were rare and usually very small or largely unfulfilled plans. For example, the Medina of Dakar was created as a planned settlement following the bubonic plague of 1914 , but later grandiose plans for its improvement were never carried out (Betts 1969). The 'concessions' of Treichville and Adjamé in Abidjan similarly got little attention (Cohen 1974). The British built estates for Accra residents displaced by the 1939 earthquake and to relieve congestion in Sekondi/Takoradi (Abloh 1967: 1j-16, Busia 1950: 12-14).

Since independence, governments have been encouraged to make more elaborate plans, includ- ing whole cities such as Tema in Ghana, San Pedro in Ivory Coast and the new Nigerian capital which is now getting under way. Little has been done so far to implement the plans for Kaduna (Lock 1967) and Lagos (Koenigsberger 1963), but plans are being made for massive development of several Nigerian state capitals (e.g. Fingerhuth 1977, Mabogunje 1976). This seems a good time, therefore, to examine the response to public housing and to compare what is being provided with what the majority of the population lives in order to assess the most important felt needs and how they are being met. Surveys of residents of public housing have been carried out in Tema (Peil 1968, Potakey 1975) and Surulere in Lagos (Marris 1961, Aribiah 1975). For comparison, I will use data collected by surveys and observation in two Gambian, four Nigerian and two Ghanaian towns (including Tema: see Peil 1976). The major areas for discussion are heterogeneity, the physical and social environment, and tenants' satisfaction. 


\section{Heterogeneity}

The most obvious contrast is that public housing tends to be homogenous in that tenants of different income levels are segregated whereas private housing is of ten heterogeneous with neighbourhoods including people of many economic levels. ${ }^{1}$ This is partly because the level of rents in much public housing (itself a result of building standards) keeps out the poor, but also because building design limits flexibility. Neighbourhoods are filled with similar houses, all having the same number of rooms and let for the same rent. Although lip-service is sometimes paid to the idea of mixing residents, this is seldom translated into practice, on the assumption imported from Europe that people prefer segreation. For example, the Owerri plan (designed by a Swiss firm) provides for residential "cells . . . subdivided into a variety of lot sizes appropriate to different income groups to avoid segregation into large single-income areas", but divides housing into three non-contiguous areas of low, medium and high density (Galantay 1978: 380,382 ). Tema houses are graded from group 1 to group 4; all houses in a neighbourhood belong to the same group and the rents charged distinguish sharply between applicants.

The main cause of mixing in public housing appears to be political pressure, whereby relatively affluent applicants get houses that are supposed to go to the poor. The houses in Surulere were built to cater for owners of family houses displaced by the re-development of central Lagos, but many of these preferred to remain in the centre or move to another area with lower rent, so their places were taken by tenants and non-Lagosians who had appropriate contacts. Therefore, successful businessmen and professionals share this estate with the poorer people it was built for (Aribiah 1974, 1975). Although about 80 per cent of housing in Tema is group 4 (for low-income people) 75 per cent of flat dwellers surveyed in 1975 were earning over $£ 1,000$ per year and thus were well above the low-income group. As most houses are allotted by employers, manual workers who get group 4 houses tend to be the most stable and best paid part of the work force.

Landlords' willingness to build wherever land can be obtained and rent out extra rooms has resulted

1 Religious heterogeneity is also greater in private housing. There is no difference in ethnic heterogeneity; most houses with more than two households are ethnically mixed, and ethnic heterogeneity in both individual houses and neighethic bourhoods varies mainly with the the town (largely homogeneous, small number of groups,
large number of groups) and the presence of a large or large number of groups)
small core of indigenes. in low levels of income segregation in private housing. These are still basically communal societies, and the privacy which is enhanced by spatially separate housing is not highly valued except by the well-educated elites. As a town grows, people of varying income obtain land and put up whatever house they can afford. The result is of ten a mixture of large and small houses, with rooms which attract a variety of tenants. Housing is seen as an income-producing investment, so rich as well as poor owners of property tend to let extra rooms to strangers. People who can afford to build a house often prefer to rent a room, either because they build at home or because they can get more money by letting superior rooms and living. in poorer ones (Abloh 1967: 75). Since any tenant who can pay the rent is acceptable and tenants do not necessarily seek the best room they can afford, there is often a considerable mixture among co-tenants as well as within neighbourhoods. In Ashaiman (the private housing suburb of Tema) 59 per cent of the houses were occupied by both manual and non-manual workers, compared to 23 per cent in Tema itself.

\section{Environment}

The style of housing provided and bureaucratic control over tenants contribute to the unpopularity of public housing, especially among low income earners. Private housing usually consists of a series of rooms built around a courtyard or two rows of rooms with a central hallway and a yard at the rear for cooking, washing and sanitation. Most families rent only a single room or a 'hall and chamber', and use this space mainly for sleeping and storage; daytime activities of ten take place in the courtyard. Public housing, on the other hand, is usually organised on the assumption that family activities should take place indoors. Tenants are housed in separate or semidetached houses or in multi-storey flats; outdoor space is completely open to the public. Where communal cooking and washing facilities are provided to save costs, these are usually at some distance from individual rooms and open to the weather or to anyone who might steal what is stored there. As a result, tenants tend to ignore them and cook near their rooms. Housewives in Surulere have converted the open space at the back of their houses into compounds for family activities, and the open plan of Tema has been partly thwarted by the erection of fences and hedges to form separate family compounds.

In most parts of West African towns, residential and productive space are not segregated. A large proportion of the adult population is self-employed and it is convenient to carry on one's business 
near home. (Tenants in public housing are of ten assumed to be wage employees, but some also run businesses on the side and wives and kin who stay with them may also be self-employed.) Craftsmen use part of their rooms or areas near the house as shops and traders set up a table or kiosk near the door. Such activity conflicts with planners' expectations of segregation of functions, and attempts are usually made to prohibit it. This deprives tenants of income and of convenient places to shop; some continue as best they can and others move to more permissive areas of private housing. This partly accounts for the large numbers of craftsmen in Ashaiman and Bardo (on the outskirts of Tema and San Pedro respectively).

Public housing also interferes with the customary relationship between landlord and tenant. Although absentee landlordism is growing (especially in Lagos), the landlord or a kinsman is usually resident, in the neighbourhood, or a frequent visitor of most privately owned housing. Tenants can therefore build up a personal relationship with him or her. This often goes well beyond the purely economic; domestic conflicts are settled, advice is given and, as a result, there is more understanding of individual needs, including late payment of rent, than is possible in the public sector. Private tenants are evicted from time to time, but the public tenant feels under greater threat and finds that in order to make any complaint about his housing he must deal with a seemingly impenetrable wall of bureaucracy (Bannerman 1973).

Social relationships between neighbours are more difficult to form in public housing. Because access is highly selective and usually associated either with employment or political contacts, tenants have less opportunity than in private housing to choose their neighbours or to move if dissatisfied. Public tenants may get to know each other as co-workers or through a Tenants' Association, but their environment tends to offer fewer opportunities for meeting as neighbours than obtain in private housing areas. Because houses are usually self-contained and the street plan is efficiently organised, public tenants seldom meet at standpipes or on footpaths, and there are fewer bars or other places for informal meetings than private tenants have. Residents of Ashaiman knew more of their neighbours than those living in Tema, and household heads in Surulere were less likely to know any of their neighbours than men interviewed in Ajegunle (a suburb of Lagos), in spite of the longer tenure of Surulere residents.

\section{Satisfaction}

Public tenants are probably more stable than those in private accommodation because selectivity is greater and movement within the public sector is much more difficult. Nevertheless, the level of satisfaction with public housing is not

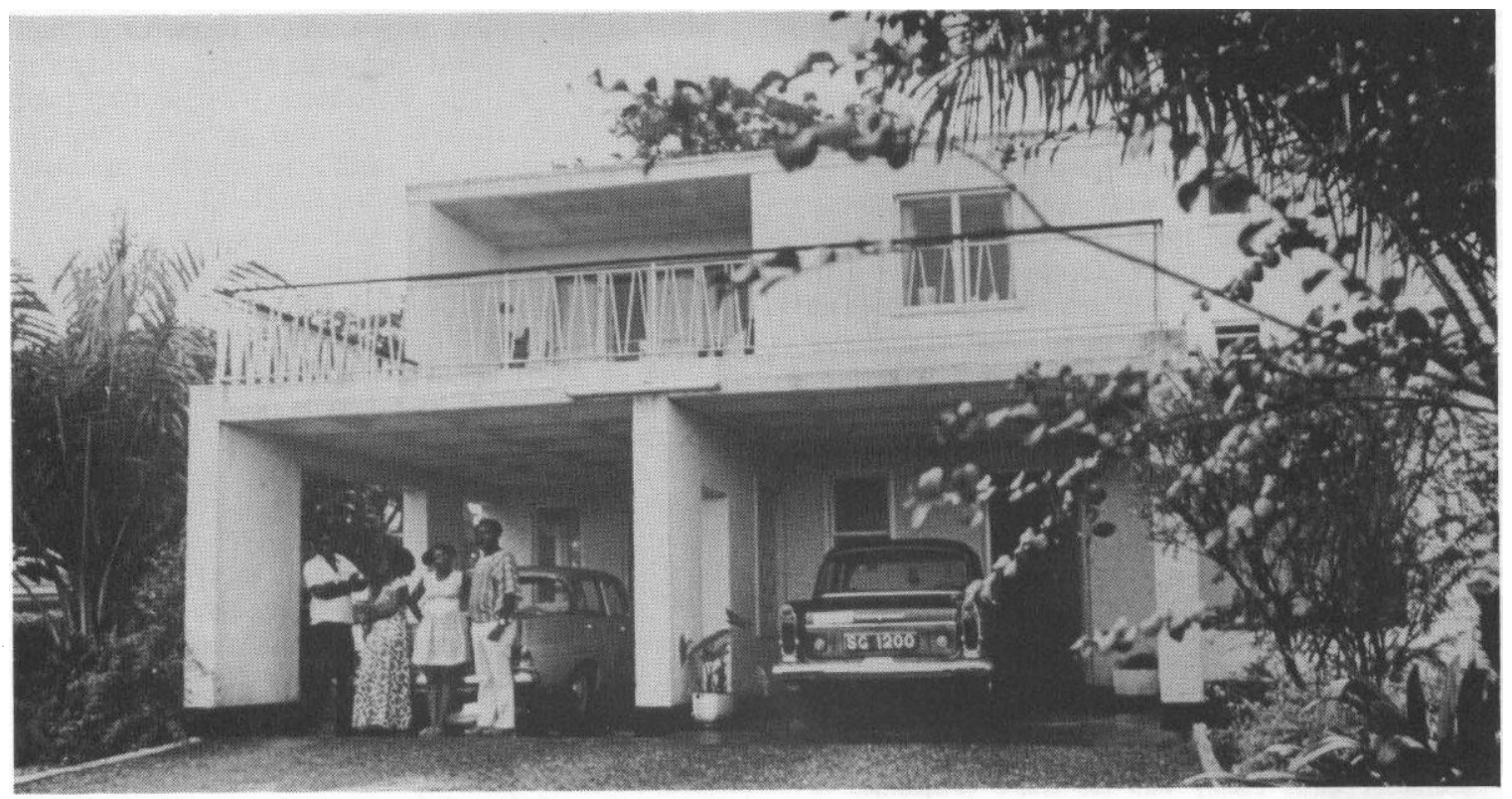


particularly high. Aribiah $(1975 ; 18)$ found that 53 per cent of former landlords and 18 per cent of former tenants would return to central Lagos if they could, even though a large majority of them had spent more than ten years in Surulere. Only 19 per cent of the tenants interviewed in the 1963 Tema survey could not name a bad feature of their house. The main sources of complaint were size, roofs and ceilings, and windows or doors (Peil 1968: 13-14). Potakey (1975: 3) reports that 43 per cent of the residents of Tema flats were dissatisfied. The major problems were size, poor maintenance and lack of privacy (they would have preferred a house).

The complaints about size are a direct response to overcrowding. It is common for more people to live in these flats or houses than they were designed for, because little account is taken of the average size of African households. The average size is seldom below three people except where most of the population are young, unmarried males. Households averaged 4.5 and 5.6 people in Tema group 4 and group 3 housing respectively, and 5.0 or more in one of the Nigerian and both Gambian towns studied. Since most public housing is for families, it should be designed to accommodate at least five people. Space is also needed for the storage of the paraphernalia of selfemployment. Frequent reports of the closing in of verandahs and the conversion of kitchens and baths into sleeping rooms are a measure of the pressure on space.

Potakey (ibid.) reports that the average flat had 2.0 persons per room. My 1968 survey found that the average in group 4 houses was 3.0 per room, about the same as private housing in Aba and Ajegunle and higher than the other towns studied. Group 3 housing averaged 1.8 per room, with 13 per cent of households having over 2.5 persons per room (counting children under 5 as half), compared to 48 per cent in the low income houses. Thus, crowding varies with income, but is as widespread in public as in private housing.

Two causes of crowding are the level of rents and the availability of alternative housing. Hake (1977: 144) points out that "When a family is living on the edge of poverty, it is a responsible decision to eat well and to sleep crowded rather than to spend the whole income on rent and to skimp on diet". When transportation costs also enter the equation, the family with an opportunity of public housing may decide to rcrowd into a conveniently located room on an estate (and profit from its water supply and electricity) rather than pay equivalent rent for more rooms with less amenities and have to pay for transport. Insofar as inflation has raised the cost of private rooms nearer the level of public rooms (and sometimes above them), anyone who can get public housing will make this decision, and it will take very considerable pressure to make some members of an overcrowded household move out.

When private rents are much lower, the decision to move is more readily taken. Ashaiman rents were less than half those in Tema in 1968, and a quarter of Ashaiman household heads had previously lived in Tema. Haeringer (1973) suggests that rents for public housing in San Pedro were so high that few ordinary people could afford to live there. This and the slow growth of public provision in San Pedro meant that in 197325,000 of the 27,500 population of the area lived in Bardo, the 'self help' suburb. An added advantage of Bardo, as of Ashaiman, is that long-term residents can own their own houses, increasing their monthly income rather than having to pay rent. The necessity of paying rent was a continued source of dissatisfaction to former landlords in Surulere (Aribiah 1975).

Government promotion of its schemes often gives rise to unrealistic expectations of what the Authority can and will do for its tenants. The provision of markets, schools and health facilities often lags well behind the building of houses, and maintenance of the latter is usually inadequate. Where public tenants come from inner-city areas, they are used to having such amenities nearby and are likely to be bitterly critical if they are not provided. Examples of the problem are the complaints of early Surulere residents and of people who moved into the FESTAC houses on the outskirts of Lagos in 1978 that they had been moved out to the 'bush'. This source of dissatisfaction may be partly overcome in time, but plans are seldom fully carried out.

Public Housing is often touted as helping to alleviate congestion, but it seldom makes much impact and is often a negative force. More people may be displaced than are housed through government schemes. For example, Hale (1977: 99) reports that by November 1971 the Nairobi government had demolished 8,943 dwelling units, while building less than a quarter as many, and had made 48,000 people homeless. These people, and others like them in many other towns, have usually moved into already overcrowded central areas or squatted on the outskirts. They and the large numbers of new arrivals must be catered for by private landlords if they are to be housed at all. Since most housing is and will continue to be 
privately owned, urban planners should not make it more dificult for owners to provide for all income groups. (Various aspects of this private provision are examined in Peil, 1976 and 1978.)

Rents are lowest where prospective builders have relatively easy access to land and are not required to put up high standard buildings. Muench (1972: 42) found that house building was considerably easier to organize in Ibadan than in Kampala, and that rents for comparable accommodation were lower in the former. Rents for private accommodation have generally risen far more slowly than the cost of living in Ghana and Nigeria; the greatest increases appear to be in Lagos, where the shortages of rooms and building land are most notable. Cohen (1974: 35) reports that building requirements in Abidjan have forced low cost builders and their tenants into squatter settlements beyond the city limits. While crowding is related to the rate of growth as well as the level of rents, it is more likely to be kept within manageable limits if private building of low rent accommodation is encouraged than if the government arrogates this function or makes regulations which discourage private owners from undertaking it.

\section{Conclusion}

Public housing in West Africa largely ignores the needs of the poor, interferes with the normal heterogeneity of neighbourhoods and promotes dissatisfaction by promising more than can be delivered and building to suit European rather than African ways of life. Large amounts of public funds are being spent on those who can best afford to provide for themselves. Expanded government control over land and housing markets seems likely to increase the development of unserviced slum settlements, whether these are officially designated as squatting or not. Given the provision of basic infrastructure and stricter control over land speculation, the private housing market is likely to do a better, if less tidy, job of housing urban residents.

\section{References}

Abloh, F., 1967, Growth of Towns in Ghana, Department of Housing and Planning Research, University of Science and Technology, Kumasi

Aribiah, O., 1974, "The Politics of Rehousing", Lagos Notes and Records 5: 5-13

-1975, "Community creation in a housing estate", unpublished manuscript

Bannerman, J. Y., 1973, The Cry for Justice in Tema (Ghana), Tema Industrial Mission
Betts, R. F., 1969, "The problem of the Medina in the urban planning of Dakar, Senegal", A frican Urban Notes, 4 (No. 3): 5-15

Busia, K. A., 1950, Report on a Social Survey of Sekondi-Takoradi, Crown Agents for the Colonies, London

Cohen, M. A., 1974, Urban Policy and Political Conflict in Africa, University of Chicago Press

Fingerhuth and Partners, 1977, Imo State Capital Owerri: Master Plan Twin City, Owerri and and Zurich

Galantay, E. Y., 1978, "The planning of Owerri", Town Planning Review, 49: 371-86

Haeringer, P., 1973, "San-Pedro 1969: La premiere vague d'immigrants" and "San-Pedro 1973: Quatre années d'evolution", Cahiers OSTROM, Série Sciences Humaines, 10: 24587

Hake, A., 1977, African Metropolis: Nairobi's Self-help City, Chatto and Windus for Sussex University Press, London

Koenigsberger, O., et al, 1963, Metropolitan Lagos, United Nations Programme of Technical Assistance. Report prepared for the Ministry of Lagos Affairs of the Federal Government of Nigeria

Max Lock and Partners, 1967, Kaduna 19171967-2017, London

Mabogunje, A. L., 1976, Plan for Akure, Capital of Ondo State, Nigeria, Office of the Permanent Secretary, Ministry of Works and Planning, Akure

Marris, P., 1961, Family and Social Change in an African City, Routledge and Kegan Paul, London

Muench, L. H., 1972, "Town planning and the social system", in M. Koll (ed.), African Urban Development, Bertelsmann Universitatsverlag, Frieburg

Peil, M., 1968, "Reactions to estate housing: a survey of Tema", Ghana Journal of Sociology, 4: $1-18$

-1976, "African squatter settlements", Urban Studies, 13: 155-66

-1978, "The search for a place to live", West Africa (London), No. 3182

Potakey, A., 1975, "Tema flats survey", Tedeco Tema), 2: 2-7 